Egypt. J. of Nutrition and Health Vol. 15 No. 2 July (2020)

\title{
RELATION BETWEEN DEPRESSION AND NUTRITIONAL STATUS AMONG ELDERLY AND IMPLEMENTATION OF GERIATRIC PROMOTIVE SERVICES IN PRIMARY HEALTH CARE
}

\author{
Hend Samy \\ Public Health Department, Faculty of Medicine, Cairo University
}

\begin{abstract}
There is accelerating growth in elderly population worldwide. Depression and malnutrition are main problems among elderly. They are strongly related.The study aimed firstly, to determine prevalence of depression among elderly. Secondly, find out the relation between depression and malnutrition. Thirdly introduce geriatric promotive, preventative and curative unit in the family health center (FHC).In this experimental study conducted in a FHC included 356 elderly considering the inclusion and exclusion criteria. The data was collected using geriatric depression scale 15 (GDS-15) questionnaire , mini nutritional assessment (MNA) and anthropometric measurement took place .Then introduction of geriatric services unit in the FHC .It was shown that $59 \%$ had moderate depression, $62 \%$ were malnourished and $75.8 \%$ had VIT D deficiency.Nutritional status significantly associated with depression $(P<0.01)$. The GDS-15 score significantly correlated with both MNA-15 and VIT $D(p<0.01)$ Elderly individuals suffer from depressive symptoms and malnutrition with high prevalence. Depression is correlated with malnutrition and VIT D status. There is a need for enhancement of geriatric health services.
\end{abstract}

Key words: Depression, Nutritional status, Vitamin D, Elderly

\section{Introduction}

Aging is inescapable event (Arslantas et al., 2014).There is accelerating growth in elderly population worldwide. According to United Nations World Population Ageing, (2015) 12.3\% of the world population were 60 years old and above and it is projected to reach $21.5 \%$, by the year 2050 . In Egypt, $7.2 \%$ of the population aged above 60 and expected to increase by $10.9 \%$ by the year 2026 (EISherbiny et al., 2015). Elderly suffer from age related illness. Depression is considered one of the most common diseases (Taheri Tanjanai et al., 2016). World Health Organization (WHO),(2017) estimated the world wide prevalence of depression among elderly was between 10 and $20 \%$. In Western countries the estimated prevalence of major depression among persons above 50 years old was $16.5 \%$ (Prashanth et al., 2015). Depression among elderly is a significant public health problem. It leads to harmful consequences especially in developing low income countries (Pilania et al., 2017).Depression is considered an important reason of decreasing quality of life and the second main cause of disability (Taheri Tanjanai et al., 2017). It accelerates functional impairment and interferes with rehabilitation therapies(Nicholson, 2011). Depression leads to impairment thinking, loss of concentration and cognitive impairment. Elderly with depression can have suicidal attempts, and selfdestructive thoughts (Prashanth et al., 2015). Depression also increases medical burden and has negative economic consequences (Mcintyre et al., 2020). Depression and malnutrition including VIT D deficiency are highly prevalent among elderly and were shown to be strongly related. The relation between them is intuitive and till now causal relationship is still unclear. Depression comes up with loss 


\section{Hend Samy}

of appetite, decreases nutrient intake and changes in weight. It was indicated that neurotransmitters and changes in hormonal profile occurring in depression are responsible for appetite loss. On the other hand poor nutrition and low serum level of VIT D induces psychiatric problems including depression (Cuomo et al., 2019). Dietary supplements are essential for emotional control and can be protective against depression. Moreover the risk factors of depression and malnutrition are common for example living lonely, absence of social support, functional and endocrinal impairment (Al-Rasheed et al., 2018).

The increased number of elderly accompanied with illness creates a growing need for adopting new strategies and promoting specialized geriatrics healthcare services especially for mental health. This can help in protecting elderly, monitoring of their health status, screening of deficiency, applying corrective actions and ensuring better quality of life.Elderly in Egypt are economically dependent(Khafajy, 2010).The health care system is facing a challenge of provision of cost effective health care with high quality for the elderly. The current health care services either preventative or curative are suboptimal and can lead to undesired outcomes and being elderly will suffer from negligence(Aly et al., 2018).In Egypt the data on the prevalence of depression and malnutrition among elderly are limited and haven't been well studied(Aly et al., 2018).

The aim of the current study firstly, to determine prevalence of depression among elderly in the catchment area of the family Health Center (FHC). Secondly, find out the relation between depression and malnutrition. Thirdly introduce geriatric promotive, preventative and curative unit in the FHC.

\section{Patients and Methods}

\section{Study design and settings}

This experimental study was conducted at the catchment area of one of theurban family health centers located in Giza governorate in a low socioeconomic area. The center provides comprehensive integrated services for the whole family. The FHC supports continuity of care and integration of health services, by using the family files that includes demographic, medical information, earlier complaints, diagnosis, treatment or any other provided services for every member in the family. The study was done from June 2017 to January 2019.

\section{Study phases}

\section{1- $\quad$ Exploratory phase}

\section{Study population and sampling}

According to the department of statistics in the district the number of residential buildings in the catchment area of the FHC was2920, and the estimated population was 30000 (28639) person as stated by the census conducted by national heath registration system 2016.

The sample size was calculated using the single population proportion formula. By assuming that the prevalence of depression among elderly was $62.7 \%$ according to a study done in Sohag governorate, Egypt (Aly et al., 2018), with 95\% confidence interval and 5\% margin of error. Accordingly, the sample size was found to be 356 participants.

Residential buildings were selected by systematic random sampling (every tenth house) for recruitment of elderly (aged $\geq 60$ years) to participate in the study. The researcher arranged with the district manager to perform outreach visits for the households. Arrangement of the teams took place. 


\section{Egypt. J. of Nutrition and Health Vol. 15 No. 2 July (2020)}

The teams consisted of nurses and social services specialists. The researcher divided and trained the teams to perform the structured interview with the participants. Each team was assigned to three to four residential buildings each day. Any building with no elderly persons was passed over and the next houses were reviewed till finding a house with an elderly person. The process was continued as systematic random sampling from the last house that was reviewed.

\section{Inclusion criteria}

Elderly individuals (aged $\geq 60$ years) who agreed about the participation in the study were included after explaining to them thepurpose of the study, ensuring confidentiality of data and receiving informed consent.

\section{Exclusion criteria}

Any individual with communication difficulties; having speaking or hearing problems, suffering from severe illness or mental problems affecting the cognitive function were excluded from the study.

None of the participants were taking VIT D supplement or anti-depressant drugs.

\section{Data collection}

Face to face interviews were conducted using structured questionnaires.

1- Socio- demographic characteristics of the participants(Fahmy et al., 2015).

2- 15-item Geriatric Depression Scale (GDS-15)

Geriatric Depression Scale - GDS is a valid and reliable scale.The Arabic form of the questionnaire was used in this study. The questionnaire consists of 15 items answered with "Yes" and "No". It took about 3 to 5 minutes to be completed. The minimum score 0 (normal) and max score 15 (severe depression). The severity is categorized as follows (Sarkar et al., 2015).

- $\quad$ 0-5 no depression (normal)

- 6-10 moderate depression

- 11-15 severe depression

3- $\quad$ Anthropometric measures: including weight,height, mid-arm circumference (MAC), waist circumference, calf circumference, and calculation of body mass index (BMI)(Marfell-Jones et al., 2006).

\section{4- $\quad$ Nutritional assessment by Mini Nutritional Assessment Short Form (MNA-SF)}

It is a reliable, well validated, simple, noninvasive and easy tool for early detection of malnutrition among elderly people.

The minimum score is 0 and maximum score is 14 (Chu et al., 2016).

- $\quad$ Scores of below 8 showed malnutrition

- $\quad$ From 8 to 11 showing risk of malnutrition

- $\quad$ Above 11 showed normal nutritional status

\section{5- $\quad$ Assessment of vitamin D}

First it was agreed with a medical laboratory to conduct vitamin D analysis for the participants and taking the blood samples at their home. The lab technicians took the samples labeled tubes and deliver them to the lab according to the standardized protocols. The participants were informed about the results.

The individuals were categorized according to serum level of VIT D according to the lab references as follows:

$\leq 20 \mathrm{ng} / \mathrm{ml}$ deficiency

21-29 ng/ml insufficiency

$>29 \mathrm{ng} / \mathrm{ml}$ considered normal 


\section{Hend Samy}

\section{2- $\quad$ Experimental phase}

Arrangement with the district manager took place to introduce geriatric promotive services unit .It included health education and increasing awareness of elderly including nutritional education session and personalized meal planning and preparation, screening for depression and malnutrition, sleeping disorders physical function and nutritional assessment, out- reach visits. The unit provided screening of chronic diseases among high risk individuals, management of mild common diseases and referral services. The health care in the unit is provided by family physicians and general practitioners. The center announced the launching of the unit. Then following up of the follow rate of the unit for a period of six months was done.

Three health education sessions were implemented in the FHC geriatric unit. Each session took about one and half hour. Topics discussed included importance of vitamin D, sources, symptoms of deficiency, and benefits of supplementation.

\section{Statistical analysis}

Data was analyzed by the Statistical Package for the Social Science Version 22 (IBM Corp., Armonk, NY, USA) .Qualitative data were presented as numbers and percentages and quantitative data by means \pm SDs. Chi-squared test was used for comparing the qualitative variables and independent sample t-test for quantitative variables. Calculation of Pearson correlation coefficients for the linear relations between GDS total scores MNA-SF and level of VIT D. Significance level was evaluated at $\mathrm{P} \leq 0.05$.

\section{Ethical considerations}

All approvals were obtained. The researcher respected all the principles of ethics of the Helsinki declarations. The interviewer explained to the participants the purpose of the study and assured them about confidentiality of their responses and signed consent was obtained from them.

\section{Results}

A total of 356 elderly individuals participated in the study; More than half $58.7 \%$ were females. The mean age of the participants was 71.4 ( $S D \pm 8.16)$ years. Nearly two third were illiterate, the majority of the married participants and those living with their spouse were females $(76,72$ and $72 \%$ respectively).Most of employed participants were males $74 \%$. 
Egypt. J. of Nutrition and Health Vol. 15 No. 2 July (2020)

Table 1.

Socio-demographic characteristics of the studied elderly persons (Total $\mathrm{N}=356$ )

\begin{tabular}{|c|c|c|c|c|c|c|}
\hline \multicolumn{2}{|c|}{ Demographic characteristics } & \multicolumn{2}{|c|}{$\begin{array}{l}\text { Female } \\
(n=209)\end{array}$} & \multicolumn{2}{|c|}{$\begin{array}{c}\text { Male } \\
(n=147)\end{array}$} & \multirow{3}{*}{$\begin{array}{l}\text { otal } \\
197\end{array}$} \\
\hline & & NO. & $\%$ & $\mathrm{NO}$ & $\%$ & \\
\hline \multirow{3}{*}{ Age } & $60-$ & 109 & 55 & 88 & 45 & \\
\hline & $70-$ & 61 & 65 & 33 & 35 & 94 \\
\hline & $80-$ & 39 & 60 & 26 & 40 & 65 \\
\hline \multirow{3}{*}{$\begin{array}{l}\text { Educational } \\
\text { Status }\end{array}$} & Illiterate & 130 & 76 & 41 & 24 & 171 \\
\hline & Primary & 41 & 45 & 51 & 55 & 92 \\
\hline & Secondary \& above & 38 & 41 & 55 & 59 & 93 \\
\hline \multirow{4}{*}{$\begin{array}{l}\text { Marital } \\
\text { status }\end{array}$} & Married & 36 & 72 & 14 & 28 & 50 \\
\hline & Widowed & 119 & 52 & 110 & 48 & 229 \\
\hline & Single & 13 & 68 & 6 & 32 & 19 \\
\hline & Separated/ divorced & 41 & 71 & 17 & 29 & 58 \\
\hline \multirow{4}{*}{ Occupation } & $\begin{array}{c}\text { Employed (in Private or } \\
\text { governmental organization) }\end{array}$ & 6 & 26 & 17 & 74 & 23 \\
\hline & Retired & 12 & 44 & 15 & 56 & 27 \\
\hline & Self employed & 19 & 40 & 28 & 60 & 47 \\
\hline & Not working & 172 & 66 & 87 & 34 & 259 \\
\hline \multirow{4}{*}{$\begin{array}{l}\text { Living } \\
\text { arrangement }\end{array}$} & Spouse & 36 & 72 & 14 & 28 & 50 \\
\hline & Children & 115 & 52 & 105 & 48 & 220 \\
\hline & Alone & 39 & 63 & 23 & 37 & 62 \\
\hline & Others & 19 & 79 & 5 & 21 & 24 \\
\hline
\end{tabular}




\section{Hend Samy}

\section{Level of depression}

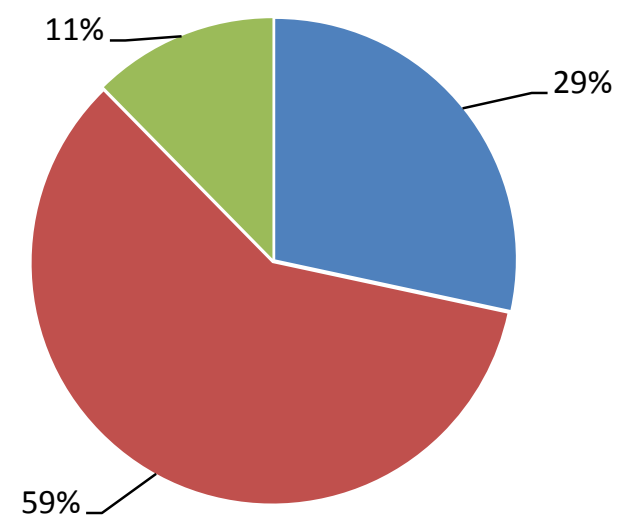

No depression

Moderate depression

- Severe depession

Figure 1:

Percent distribution of the studied elderly persons according to the level of depression Regarding levels of depression as shown in figure 1 most of the participants 211 (59\%) had moderate depression and $44(11 \%)$ participants suffered from severe depression.

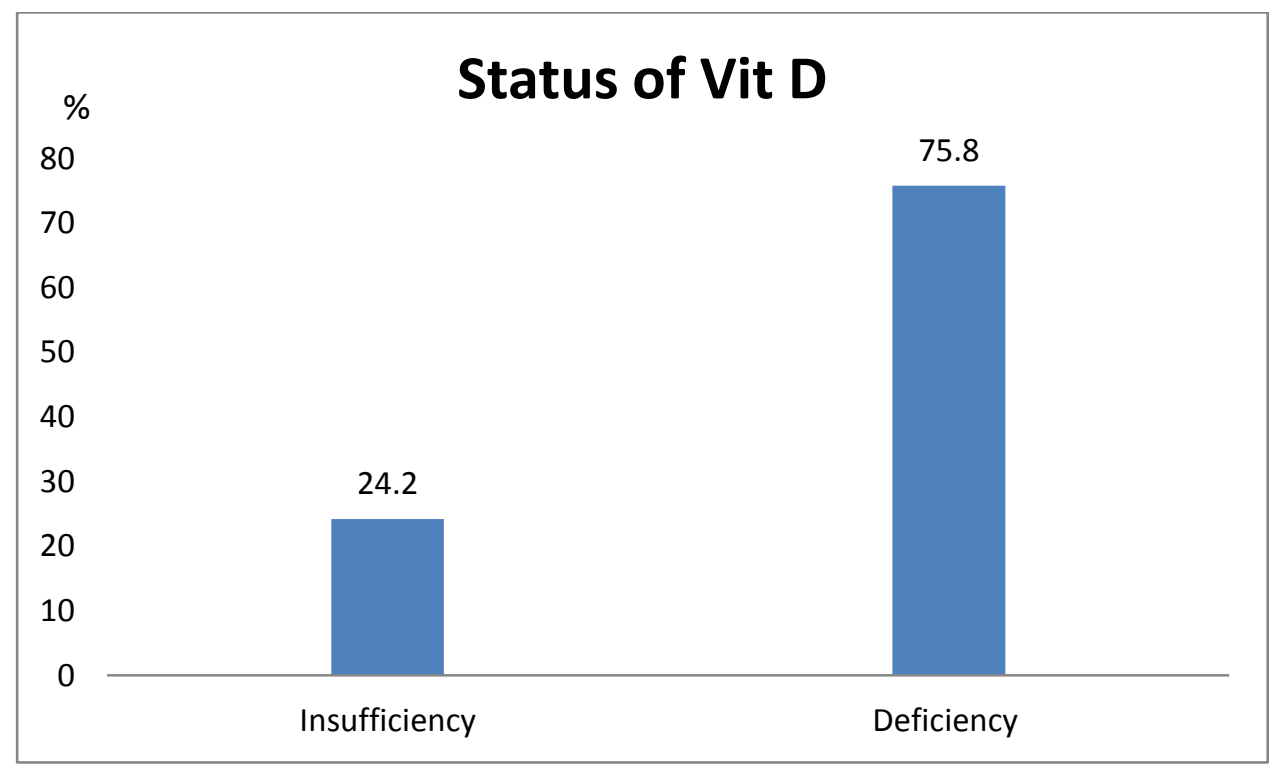

Figure 2:

Percent distribution of the studied elderly individuals according to their VIT D status As shown in Figure 2 nearly three quarters of the participants (270) 75.8\% had VIT D deficiency and $(86) 24.2 \%$ had VIT D insufficiency.

The Comparison between the nutritional status among elderly individuals with depressive and without depressive symptoms is shown in table 2 . The majority of elderly individuals who had depressive symptoms were malnourished $77.6 \%$ based on MNA-SF. Nearly half of those with no depressive sysmptoms $47.5 \%$ were in a normal nutritional status. The difference between groups were significant $p<0.01$. 
Egypt. J. of Nutrition and Health Vol. 15 No. 2 July (2020)

Table 2:

Nutritional status in elderly individuals with depressive symptoms compared to elderly individuals with no depressive symptoms

\begin{tabular}{|c|c|c|c|c|c|}
\hline \multirow[t]{2}{*}{ Nutritional status ${ }^{a}$} & \multicolumn{2}{|c|}{$\begin{array}{c}\text { Depressive } \\
\text { symptoms }(n=255)\end{array}$} & \multicolumn{2}{|c|}{$\begin{array}{c}\text { No depressive } \\
\text { symptoms }(n=101)\end{array}$} & \multirow[t]{2}{*}{$P$ value $\dagger$} \\
\hline & NO. & $\%$ & NO. & $\%$ & \\
\hline Malnutrition( $\mathrm{n}=221)$ & 198 & 77.6 & 23 & 22.8 & \multirow{3}{*}{$<0.01^{\star}$} \\
\hline Risk of malnutrition $(n=75)$ & 45 & 17.6 & 30 & 29.7 & \\
\hline $\begin{array}{l}\text { Normal nutritional } \\
\text { status }(\mathrm{n}=60)\end{array}$ & 12 & 4.7 & 48 & 47.5 & \\
\hline
\end{tabular}

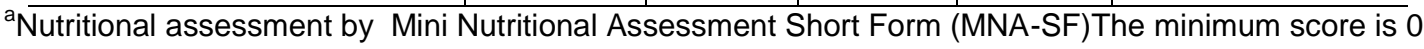
and maximum score is 14,Scores of below 8 showed malnutrition ,From 8 to 11 showing risk of malnutrition, Above 11 showed normal nutritional status ${ }^{8}$

$\dagger$ Chi square test

${ }^{*} P$ value $<0.05$ considered significant

Anthropometric variables in elderly participants. with depressive symptoms compared to elderly with no depressive symptoms are listed in table $\mathbf{3}$. Elderly with depressive symptoms have significantly higher Body Mass Index (BMI) and Triceps Skin Fold thickness (TSF) than those with no depressive symptoms $(p<0.01)$. Depression was higher among obese, over weight and underweight elderly individuals while lower depression was among participants with normal weight and the difference between groups were significant $(P<0.01)$.

Table 3:

Anthropometric variables in elderly patients with depressive symptoms compared to elderly patients with no depressive symptoms

\begin{tabular}{|c|c|c|c|}
\hline & $\begin{array}{c}\text { Depressive } \\
\text { symptoms }(n=255)\end{array}$ & $\begin{array}{c}\text { No depressive } \\
\text { symptoms } \\
(n=101)\end{array}$ & $P$ value * \\
\hline $\mathrm{BMI}^{\mathrm{a}}$ category & No $\%$ & No $\%$ & \\
\hline Normal weigh & $23 \quad(9 \%)$ & $39 \quad(38.6 \%)$ & \multirow{5}{*}{$<0.01$} \\
\hline Under weight & $\begin{array}{ll}60 & (23.5 \%)\end{array}$ & $29 \quad(28.7 \%)$ & \\
\hline Over weight & $\begin{array}{ll}77 & (30.2 \%)\end{array}$ & $14 \quad(13.9 \%)$ & \\
\hline \multirow[t]{2}{*}{ Obese } & $\begin{array}{ll}95 & (37.3 \%)\end{array}$ & $19 \quad(18.8 \%)$ & \\
\hline & $m \pm S D$ & $m \pm S D$ & \\
\hline $\mathrm{TSF}^{\mathrm{b}}$ & $19.6 \pm 2.01$ & $17.9 \pm 3.2$ & $<0.01$ \\
\hline $\operatorname{MAC}^{\mathrm{C}}(\mathrm{cm})$ & $27.1 \pm 5.3$ & $26.8 \pm 6.6$ & 0.6 \\
\hline Waist circumference $(\mathrm{cm})$ & $86.9 \pm 7.36$ & $85.4 \pm 8.93$ & 0.1 \\
\hline Calf circumference $(\mathrm{cm})$ & $31.3 \pm 2.8$ & $31.9 \pm 3.33$ & 0.08 \\
\hline
\end{tabular}

${ }^{*} \mathrm{P}$ value $<0.05$ considered significant

a BMI: Body Mass Index

b TSF: Triceps Skin Fold thickness

c MAC: Mid Arm Circumference 


\section{Hend Samy}

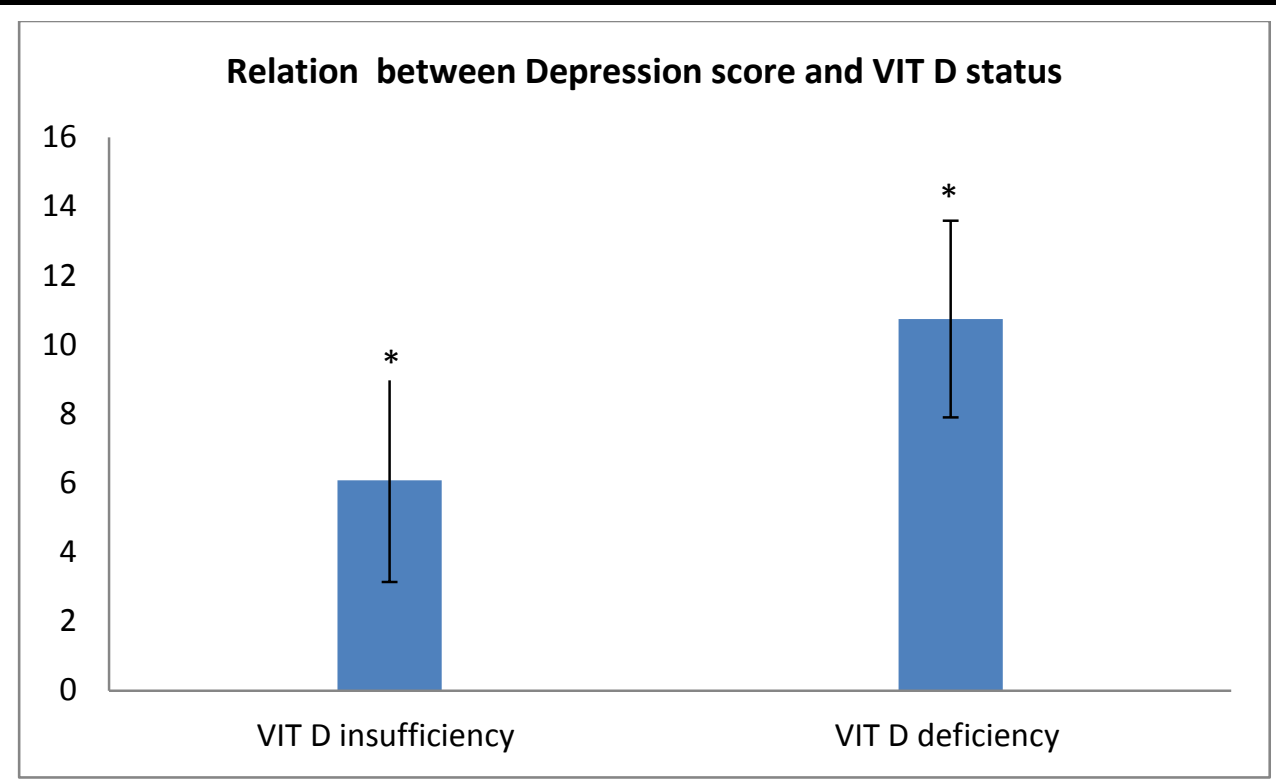

Figure 3:

Relation between mean depression score and Vit D status

As shown in figure 3 the mean score of GDS -15 in elderly individuals with VIT D insufficiency was $6(S D \pm 2.9)$.Elderly individuals who had VIT D deficiency had higher mean GDS-15 score 11 $(S D \pm 2.8)$, and the difference between the groups was significant $p<0.01$

Table 4 shows the correlation analysis, there's a statistically negative correlation between GDS-15 with both MNA-SF $(r=0.632)$ and VIT $D(r=-0.565), p<0.01$.

Table 4:

Correlation between Depression scores and VIT D nutritional status

\begin{tabular}{c|c|c}
\hline & MNA-SF $^{b}$ & VIT D \\
\hline Pearson Correlation ( $r)$ & -0.632 & $-0.565^{\star *}$ \\
\hline P value & $<0.01$ & $<0.01$ \\
\hline
\end{tabular}

aGDS-15 Geriatric Depression Scale,

b MNA-SF Mini Nutritional Assessment Short Form

${ }^{\star *}$ Correlation is significant at the 0.01 level (2-tailed). 


\section{Egypt. J. of Nutrition and Health Vol. 15 No. 2 July (2020)}

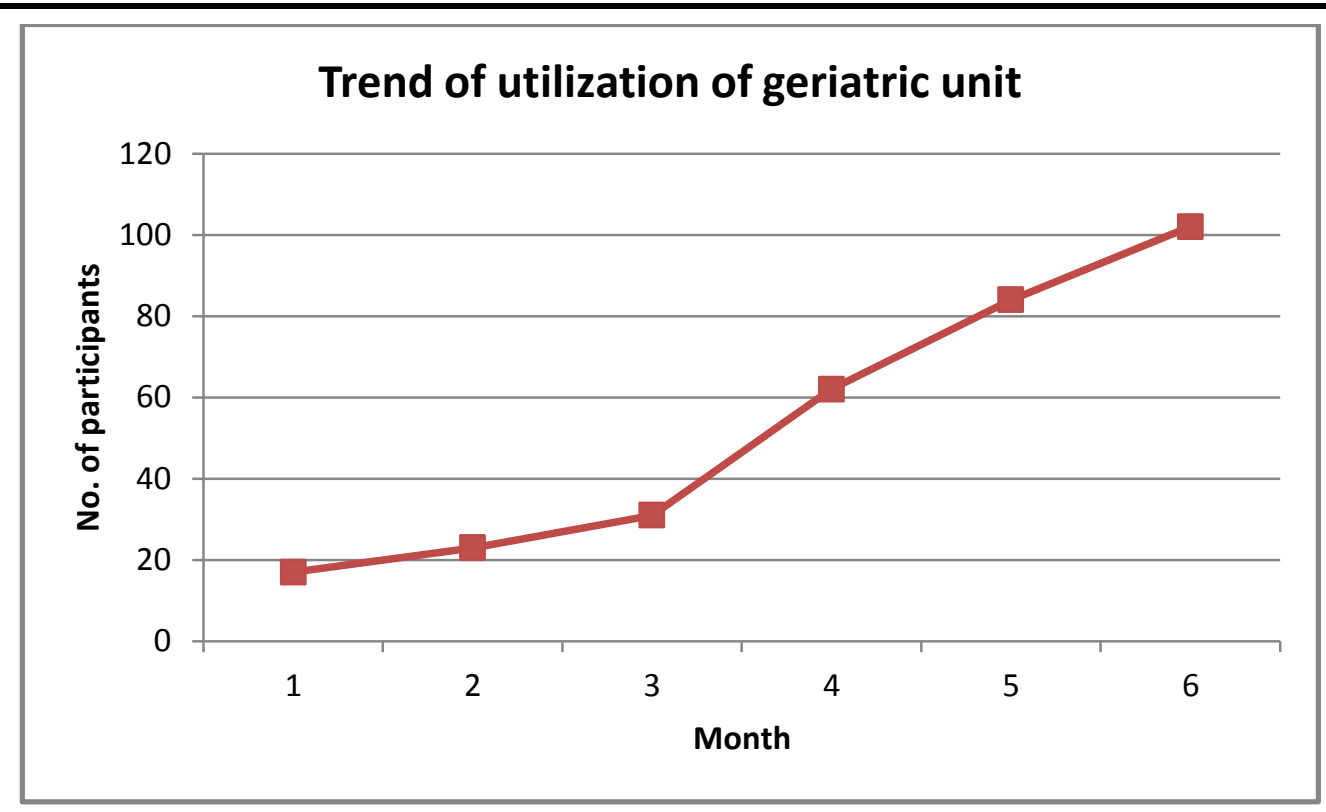

Figure 4:

Trend of utilization of geriatric unit by elderly at the FHC

As shown in figure 4 by following up the introduced geriatric unit for a period of 6 months there was increase in the number of visitors from 17 visitors at the first month reaching 102 at the end of the sixth month.

\section{Discussion}

The relation between depression and Malnutrition is complicated. Depression can cause loss of appetite and malnutrition. Also malnutrition can negatively impact depression. There is not a firm conclusion regarding the causal relationship between depression and nutritional status (Al-Rasheed et al., 2018).

\section{Prevalence of depression among elderly individuals}

Depression in geriatric is a frequently occurring problem that is seldom detected and treated. It has adverse consequences and can result in disability. So, it is necessary to study the disease and its associated factors(Al-Rasheed et al., 2018).

In the current study, the prevalence of depression among elder individuals was $70 \%$ (59\% moderate depression and $11 \%$ with severe depression). The finding was nearly similar to other findings in numerous previous studies in Egypt. For instance, A study done in Alexandria showed the prevalence of depression was $74.5 \%(E l-S h e r b i n y ~ e t ~ a l ., 2016)$, Also the prevalence of depression among elderly attending Zagazig University Hospital in Egypt was 72\% (Esmayel et al., 2013), Additionally the study finding was higher another study done Cairo which depicted that the prevalence of depression among elderly attending primary care clinics was 54.3\%(EL Kady et al., 2013). Finally $62.7 \%$ of participated elderly were suffering from depression in a community-based study in Sohag (Aly et al., 2018). These differences can be attributed to variations in the areas of study and the socioeconomic level of the participants.

The current study findings were lower than that of $\boldsymbol{A h m e d}$ et al, (2014) who found that $80 \%$ of geriatric homes residents in Cairo were suffering from depression, anxiety, or both of them. This 


\section{Hend Samy}

elevated prevalence may be due to living alone without family members who provide support and can buffer stressors (El-Sherbiny et al., 2016).

The prevalence of depression among elderly in the current study was much higher than that reported in previous studies done in other countries as it was $32.8 \%$ in china(Zou et al., 2018),and $16.5 \%$ in Malysia (Vanoh et al., 2016). These differences can be attributed to the different methods used and living conditions in varies studies.

\section{Depression and nutritional status}

In the present study the nutritional status and level of VIT D were assessed and analyzed in relation to depression among the elderly.

It was shown in the current study that that the prevalence of malnutrition was worrying as $62 \%$ of the elderly were malnourished and $21 \%$ were at risk of malnutrition that was higher than what was reported in previous studies. For example El desouky and Abed, (2016)found the prevalence of malnutrition among elderly in Qalyobeya Governorate was $35 \%$ while Abdelrahman and Elawam,(2012)found that it was $14.5 \%$ in their study in Cairo.Boulos et al.,(2013) found in a cross sectional study that only $8 \%$ of Lebanese elderly were malnourished. Additionally Agarwalla et al., (2015) found a prevalence of $15 \%$ in India. This high level in the current study can be explained by the low socio economic level of the studied group as that most of them were illiterate and not working that may affect their ability to buy nutritious food.

Depression and malnutrition have become an important problem among elderly. In the present study Depression was shown to be significantly correlated with Malnutrition. Other studies found independent association between depression and malnutrition .Depression can impair eating behavior, decrease appetite and hence weight reduction (Al-Rasheed et al., 2018, and Vafaei et al., 2013). On the other hand malnutrition can lead to depressive symptoms among elderly as they are psychologically vulnerable (Parke et al., 2018) and deficiency of nutrients and minerals can alter the release of neurotransmitter (Demelash, 2017).

Comparison of the anthropometric variables in individuals with depressive symptoms and those without depressive symptoms was done in the current study. It was shown that depression was higher among obese, over weight and underweight elderly individuals while lower depression was among participants with normal weight, these findings were similar to the study done by Ahmadi and his colleagues (Ahmadi et al., 2013). It was reported in a cross-sectional Korean study that obesity is significantly related with depression and underweight significantly increase the risk of depression than normal weight (Hong and Hur, 2017). Triceps skin fold thickness was significantly higher in individuals with depressive symptoms which was observed in a previous study (Ahmadi et al., 2013).

The current study showed that $78.8 \%$ of the elderly individuals had VIT D deficiency. Similarly Kweder and Eidi found in their study that only $15 \%$ of elderly people had normal serum level of VIT D (Kweder and Eidi,2018).A study done among elderly in Singapore showed that $44.0 \%$ were vitamin D deficient and $41.8 \%$ were vitamin D insufficient(Neo and Kong, 2016).Elder individuals had no proper sun light exposure, insufficient VIT D intake in diet and Lack of physical activities (Wyskida et al., 2017).

There was significant negative correlation between VIT $D$ and depression scores in the current study. Previous studies showed associations between VIT D and depression and its 


\section{Egypt. J. of Nutrition and Health Vol. 15 No. 2 July (2020)}

supplementation improved depression scores among elderly (Alavi et al., 2017). In 2016, Okereke reviewed 20 observational (cross-sectional and prospective) studies and 10 randomized trials. It was depicted in 13 observational studies an inverse relation between level of VIT D in blood and depression (Okereke and Singh, 2016).

The current study has novelty in evaluation of the association between nutritional status and VIT D with depression among elderly and introduction of geriatric unit in FHC which has not been done before in previous studies in Egypt. The unit succeeded in increasing the numbers of utilizers from 20 in the first month of its implantation reaching 120 in the sixth month. The utilizers were receiving physical function and nutritional assessment in addition to screening for malnutrition, depression, sleeping disorders, and chronic diseases. The unit provided management of mild common diseases and referral services in addition to out- reach visits for health education and screening. The unit had registration system that can support provision of data on the functional status of elderly and underlying risk factors. This will be beneficial in placing aging population in the Egyptian policy-map which was considered as challenge due to lack of relevant and reliable data(Badr and Shaheen,2017). The study has advantage as its methods were simple and was acceptable by the studied individuals.

\section{Conclusion}

It is concluded from the current study that elderly individuals suffer from depressive symptoms with high prevalence. Depression is correlated with malnutrition and VIT D status.

\section{Recommendations}

The results of the study proved that there is a need for enhancement and frequent evaluation of the geriatric program. There have to be frequent assessment of their nutritional status, VIT D level in addition to health education. It is recommended to save their data in a properly well-established information system with regular updating. That can help to identify and prioritize elderly individuals with greatest risk of depression and malnutrition as well as program evaluation. The government can provide subsidiary meals by cooperating with non-profit organizations. Primary health care is the first line of care and enhancement of geriatric services can be through wider implementation of geriatric units in primary health care centers in all governorates. 


\section{References}

Abdelrahman, H., Elawam, A. (2015) .

Nutrition status of community dwelling older population in an Egyptian upper area. JARCP, 2: 301-309.

Agarwalla, R., Saikia, A., \& Baruah, R.(2015).

Assessment of the nutritional status of the elderly and its correlates. Journal of Family and Community Medicine,22(1), 39.

Ahmadi, S. M., Mohammadi, M. R., Mostafavi, S. A., Keshavarzi, S., Kooshesh, S. M., Joulaei, H., Sarikhani, Y., Peimani, P., Heydari, S. T., \& Lankarani, K. B. (2013).

Dependence of the geriatric depression on nutritional status and anthropometric indices in elderly population. Iranian journal of psychiatry, 8(2), 92-96.

Ahmed, D., El Shair, I. H., Taher, E., \& Zyada, F. (2014).

Alavi, N. M., Khademalhoseini, S., Vakili, Z., \& Assarian, F. (2019).

Effect of vitamin $D$ supplementation on depression in elderly patients: A randomized clinical trial. Clinical nutrition (Edinburgh, Scotland), 38(5), 2065-2070.

Al-Rasheed, R., Alrasheedi, R., Johani, R. A., Alrashidi, H., Almaimany, B., Alshalawi, B., . . . Alqadheb, A. (2018).

Malnutrition in elderly and its relation to depression. International Journal Of Community Medicine And Public Health,5(6), 2156.

Aly, H. Y., Hamed, A. F., \& Mohammed, N. A. (2018).

Depression among the elderly population in Sohag governorate. Saudi medical journal, 39(2), 185-190. https://doi.org/10.15537/smj.2018.2.21353

Aly, H., Hamed, A., \& Mohammed, N. (2018).

Depression among the elderly population in sohag governorate. Saudi Medical Journal,39(2), 185-190. doi:10.15537/smj.2018.2.21353

Arslantas, D., Ünsal, A., \& Ozbabalık, D. (2013).

Prevalence of depression and associated risk factors among the elderly in Middle Anatolia, Turkey. Geriatrics \& Gerontology International,14(1), 100-108.

Boulos, C., Salameh, P. \& Barberger-Gateau, P. (2013).

The AMEL study, a cross sectional population-based survey on aging and malnutrition in 1200 elderly Lebanese living in rural settings: protocol and sample characteristics. BMC Public Health 13, 573 (2013).

Chu, C. S., Liang, C. K., Chou, M. Y., Lin, Y. T., Hsu, C. J., Chou, P. H., \& Chu, C. L. (2016).

Short-Form Mini Nutritional Assessment as a useful method of predicting the development of postoperative delirium in elderly patients undergoing orthopedic surgery. General hospital psychiatry, 38, 15-20. 


\section{Egypt. J. of Nutrition and Health Vol. 15 No. 2 July (2020)}

Cuomo, A., Maina, G., Bolognesi, S., Rosso, G., Crescenzi, B. B., Zanobini, F., . . Fagiolini, A. (2019).

Prevalence and Correlates of Vitamin D Deficiency in a Sample of 290 Inpatients With Mental Illness. Frontiers in Psychiatry,10. doi:10.3389/fpsyt.2019.00167

Demelash, S. (2017).

The Role of Micronutrient for Depressed Patients. Journal of Neuropsychopharmacology \& Mental Health,02(01).

El Kady, H. M., \& Ibrahim, H. K. (2013).

Depression among a group of elders in Alexandria, Egypt. Eastern Mediterranean health journal $=$ La revue de sante de la Mediterranee orientale $=$ al-Majallah al-sihhiyah li-sharq almutawassit, 19(2), 167-174.

El-Desouky, R., \& Abed, H. (2017).

Screening of malnutrition and its correlates among a sample of rural elderly in Qalyobeya Governorate, Egypt. Journal of Egyptian Public Health Association,92(3), 156-166. doi:10.21608/epx.2017.16394

El-Sherbiny, N. A., Younis, A., \& Masoud, M. (2016).

A comprehensive assessment of the physical, nutritional, and psychological health status of the elderly populace in the Fayoum Governorate (Egypt). Archives of Gerontology and Geriatrics,66, 119-126.

Esmayel, E. M., Eldarawy, M. M., Hassan, M. M., Mahmoud, A. A., \& Mohamed, S. Y. (2013). Mental Health Problems and Sociodemographic Correlates in Elderly Medical Inpatients in a University Hospital in Egypt. Current Gerontology and Geriatrics Research,2013, 1-4. doi:10.1155/2013/923710

Fahmy, SL., Nofal, LM., Shehata, SF., Kady, HME. and Ibrahim, HK .(2015).

Updating indicators for scaling the socioeconomic level of families for health research. Journal of the Egyptian Public Health Association, 90(1), 1-7.

Hong, S. M., \& Hur, Y. (2017).

Relationship between obesity and depression in Korean adults. Medicine,96(52).

Khafajy, G.(2010)

The role of family physician in providing comprehensive geriatric assessment [MD dissertation]. Cairo, Egypt: Faculty of Medicine, Cairo University.

Kweder, H., \& Eidi, H. (2018).

Vitamin D deficiency in elderly: Risk factors and drugs impact on vitamin D status. Avicenna Journal of Medicine,8(4), 139. doi:10.4103/ajm.ajm_20_18

Marfell-Jones, M., Olds, T., Stewart, A. and Carter, L. (2006).

International standards for anthropometric assessment. ISAK, Potchefstroom. 


\section{Hend Samy}

Mcintyre, R. S., Millson, B., \& Power, G. S. (2020).

Burden of Treatment Resistant Depression (TRD) in patients with major depressive disorder in Ontario using Institute for Clinical Evaluative Sciences (ICES) databases: Economic burden and healthcare resource utilization. Journal of Affective Disorders,277, 30-38.

Neo, J. J., \& Kong, K. H. (2016).

Prevalence of Vitamin D Deficiency in Elderly Patients Admitted to an Inpatient Rehabilitation Unit in Tropical Singapore. Rehabilitation Research and Practice,2016,1-6.

Nicholson, I. R. (2011).

New technology, old issues: Demonstrating the relevance of the Canadian Code of Ethics for Psychologists to the ever-sharper cutting edge of technology. Canadian Psychology/Psychologie Canadienne,52(3), 215-224.

Okereke, O. I., \& Singh, A. (2016).

The role of vitamin $D$ in the prevention of late-life depression. Journal of Affective Disorders, 198, 1-14.

Parke, A., Griffiths, M., Pattinson, J., \& Keatley, D. (2018).

Age-related physical and psychological vulnerability as pathways to problem gambling in older adults. Journal of Behavioral Addictions,7(1), 137-145.

Pilania, M., Bairwa, M., Khurana, H., \& Kumar, N. (2017).

Prevalence and Predictors of Depression in Community-Dwelling Elderly in Rural Haryana, India. Indian journal of community medicine : official publication of Indian Association of Preventive \& Social Medicine, 42(1), 13-18. https://doi.org/10.4103/0970-0218.199792

Prevalence and predictors of depression and anxiety among the elderly population living in geriatric homes in Cairo, Egypt. The Journal of the Egyptian Public Health Association, 89(3), 127-135.

Sarkar, S., Kattimani, S., Roy, G., Premarajan, K. C., \& Sarkar, S. (2015).

Validation of the Tamil version of short form Geriatric Depression Scale-15. Journal of neurosciences in rural practice, 6(3), 442-446. https://doi.org/10.4103/0976-3147.158800

Tanjanai, P. T., Moradinazar, M., \& Najafi, F. (2016).

Prevalence of depression and related social and physical factors amongst the Iranian elderly population in 2012. Geriatrics \& Gerontology International,17(1), 126-131. doi:10.1111/ggi.12680

United Nations. World Population Ageing, (2015).

Department of Economic and Social Affairs, Population Division.

Vafaei, Z., Mokhtari, H., Sadooghi, Z., Meamar, R., Chitsaz, A., \& Moeini, M. (2013).

Malnutrition is associated with depression in rural elderly population. Journal of research in medical sciences : the official journal of Isfahan University of Medical Sciences, 18(Suppl 1), S15-S19. 
Egypt. J. of Nutrition and Health Vol. 15 No. 2 July (2020)

Vanoh, D., Shahar, S., Yahya, H. M., \& Hamid, T. A. (2016).

Prevalence and Determinants of Depressive Disorders among Community-dwelling Older Adults: Findings from the Towards Useful Aging Study. International Journal of Gerontology,10(2), 81-85.

World Health Organization(2017).

Mental health of older adults: Fact sheet accessedat

http://www.who.int/mediacentre/factsheets/fs381/en

Wyskida, M., Wieczorowska-Tobis, K., Chudek, J.(2017).

Prevalence and factors promoting the occurrence of Vitamin D deficiency in the elderly. Postepy Hig Med Dosw (Online), 71:198-20.

Zou, C., Chen, S., Shen, J., Zheng, X., Wang, L., Guan, L., Liu, Q., \& Yang, Y. (2018).

Prevalence and associated factors of depressive symptoms among elderly inpatients of a Chinese tertiary hospital. Clinical interventions in aging, 13, 1755-1762. 


\section{Hend Samy}

العلاقه بين الإكتئاب والحاله الغذائيه لكبار السن وتطبيق خدمه تعزيز صحه المسنين في

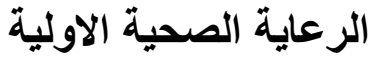

\section{هiامي}

قسم الصحة العامة وطب المجتمع كلية الطب جامعه القاهرة

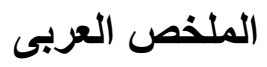

توجد زياده كبيره في عدد المسنين في انحاء العالم. فالإكتئاب وسوء التخذيه من المشاكل الأساسيه

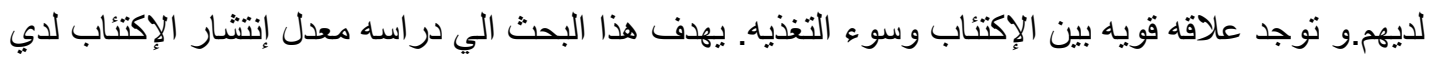
المسنين و إيجاد العلاقه بينه وبين سوء التغذيه. وكذللك عمل وحده وقائيه و علاجيه مع تعزيز صحه المسنين في مركز طب الاسرة. إحتوت هذه الدراسه التجريبيه علي وOبه شخصا مسن مع الأخذ في الإعتبار معاير

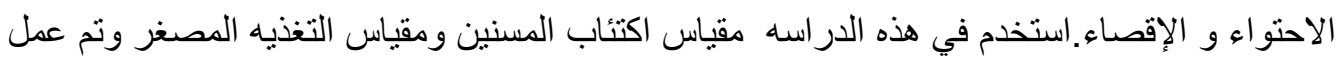
المقايس الانثروبو متريه وبعد ذللك تم إدخال وحده تعزيز صحه المسنين بالمركز ـ وجد ان 90٪ من العينه

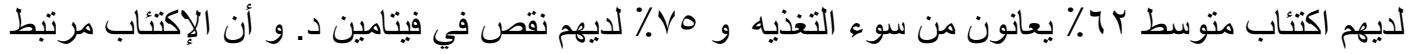
إرتباط معنوي بالحاله الغذائيه وفيتامين د، و إستتنت الدر اسه انه توجد حاجه الي إنشاء وحدات لتعزيز صحها

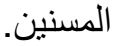
الكلمات المفتاحيه:الإكتئاب ، الحاله الغذائيه ، فيتامين د ، المسنين 